\title{
Factors Related to School Readiness in Children: A Cross-Sectional Analytic Study of Elementary School Children in Manado
}

\author{
Lydia Wangke*iD, Gregory Joey D, Nurhayati Masloman (D), Hesti Lestari(D) \\ Department of Pediatrics, Faculty of Medicine, Sam Ratulangi University, Manado, North Sulawesi, Indonesia
}

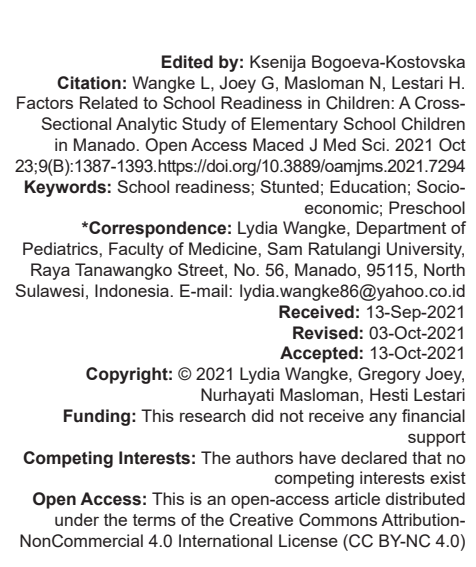

\section{Introduction}

Education is the key to each individual's future. Special preparation is needed for children before entering school so that children can show their potential in the learning process. Learning is the most vital key in any educational endeavor, as education is not achievable without actual learning process beforehand [1], [2]. School readiness is a product of the interaction between the child and the range of environmental and cultural experiences that maximize the development outcomes for children [3]. School readiness is child's readiness involves physical readiness, mental, social, emotional and intelligence, school readiness in children learning process and also family readiness which interrelated [4].

School readiness refers to whether a child is ready to make an easy and successful transition into school and the school readiness between one to another children are not same, even when they are at the same age. Children's school readiness must be prepared since early age, so that he/she will be ready for learning and educational process Children who are better prepared for school are more likely to succeed in attending education at the next level than children who are not prepared for school [5]. School readiness is an important part of an educational process for the continuity of effective learning and educational process. Children who have readiness for school will get benefit and progress in the next development. Meanwhile children which are not having forwardness, it will be frustrated if placed in an academic location [4].

In this case, there are various factors related to school readiness. These factors greatly determine the maturity of a child in entering the school world. In this study, researchers wanted to examine the factors related to school readiness, especially factors of nutritional status (height according to age), maternal employment status, maternal education status, socioeconomic status, and participation in preschool. 


\section{Methods}

\section{Study population}

Method of this study was analytic observational with cross-sectional design, conducted at 4 elementary schools (ES) in Malalayang district, using two-step random sampling between August and November $2017(n=150)$. Malalayang is the largest district with the largest population in Manado, North Sulawesi, Indonesia. The population of this study was first grade ES students aged 6 years old. Participants in this study must fulfill inclusion criteria, including first grade ES students aged 6 years old, healthy children, and parents agreed to participate in the study. Children with history of low birth weight, anemia, and missing data (blank/unfilled data in the research form) were excluded from this study.

\section{Data collection}

Study sample was obtained using two-step random sampling, by randomizing 24 ES in Malalayang district. After random in the first stage obtained a sample of $4 \mathrm{ES}$, comprised of 260 subjects. Afterward, another random sampling was conducted resulting of 150 subjects.

In one ES, eight subjects were excluded, comprised of two students with incomplete data, two students with history of low birth weight and four students with anemia. Another eight subjects then picked by random sampling to replace these excluded subjects.

School readiness in this study was assessed using Nijmeegse Schoolbekwaamheids Test (NST). The results of this NST were depicted in numerical score and will be categorized into two categories, namely ready for school and not ready for school. Assessment of school readiness was evaluated using the NST conducted by a competent psychologist.

Weight and height of the children was measured using scales and stadiometer, weight and height itself reflects growth which was an indicator of nutritional status and well-being for the individual and in populations. Stunted was determined by height for age below the $3^{\text {rd }}$ percentile based on CDC 2000 growth chart. Employment status of mothers is the working status of mothers to earn for living. Employment status of mothers is categorized in two categories, namely employed and unemployed mothers. Employed mothers are mothers who work, either from home or out of home, to earn for living, besides raising, and taking care of children at home. Unemployed mothers are mothers who are not working to make a living for the family.

Socioeconomic status in this study is based on the North Sulawesi provincial minimum wage.
Low socioeconomic status is wages of under IDR $2,598,000$ (equivalent of 180 US\$) and the middleupper socioeconomic status of IDR 2,598,000 or more, in accordance with Governor Regulation Number 46 dated November 1, 2016, stated North Sulawesi provincial minimum wage of IDR $2,598,000$, valid from January 1, 2017.

Maternal education is the highest level of education achieved by the mother. Education status in this study was dichotomized into 2 categories, high-school and non-high school graduate. Included preschool children in this study were children who attended playgroups and Child Care Centers. Preschool participation was categorized into children attended preschool and those who did not attend preschool. Research data were obtained by conducting interviews with parents. Afterward, a routine medical checkup and anthropometrics measurements were undertaken to determine that the child is in good health condition. This study was conducted under the approval from the Ethics Committee of Medical Faculty of Sam Ratulangi University in Manado. Parental informed consents were obtained before subjects' enrolment,

\section{Statistical analysis}

This study conducts univariate analysis to analyze general characteristics of subjects and reported in the form of distributive tables, depicted in mean and standard deviation (SD). Associations between each independent variable and school readiness were assessed by bivariate analysis using Chi-square, with a significant value of $p<0.001$. Assessment of collective independent variables to determine which factors have the most influence on school readiness were carried out by multivariate analysis using logistic regression, with a significant value of $p<0.001$. All data were analyzed using SPSS for Windows version 23 program.

\section{Results}

This research was conducted on first grade ES students aged 6 years old from 4 ES, selected by random sampling between August and November 2018. The total number of first grade ES students aged 6 years old in all four ES were 260 students. Of the 260 ES students conducted randomly proportionally to get 150 subjects (Figure 1 ).

Table 1 showed the distribution of study subjects based on school readiness status. From 150 subjects who were enrolled, 109 were ready for school and 41 others were not ready. There was no significant difference of school readiness based on children's age, whereas the mean age of subjects was 6 years. This research also found significant difference 


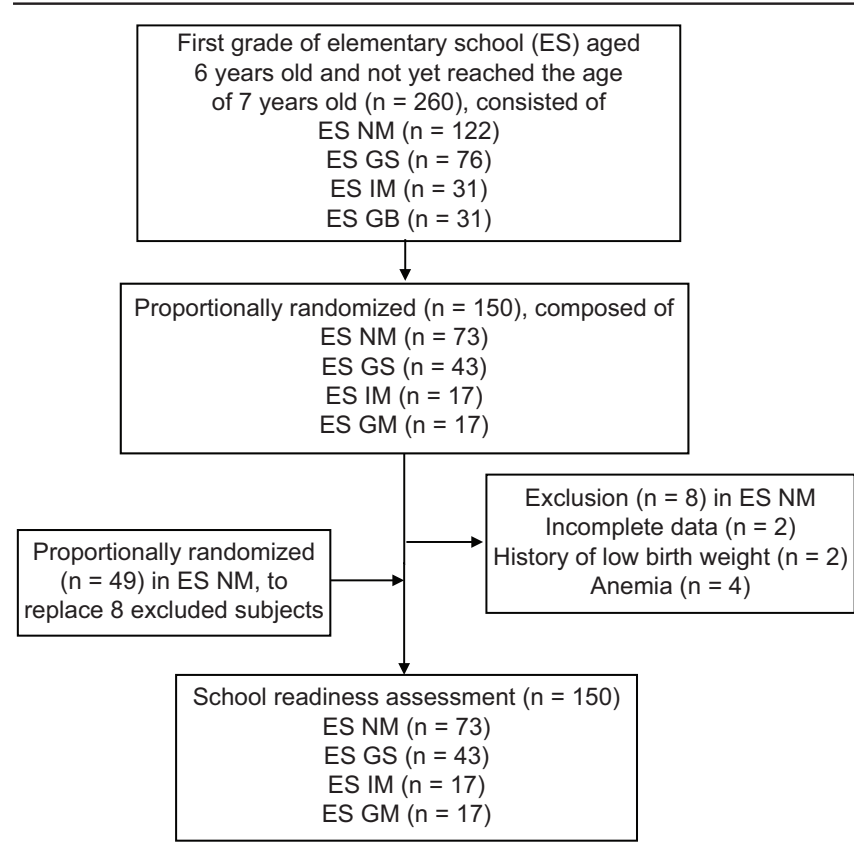

Figure 1. Research Sampling Flow Chart

of school readiness based on gender. Female children were somewhat more prepared to school than its male counterparts. Based on anthropometric status, the body height and body weight were differ significantly among the two groups. Mean body weight and body height of children who were ready for school was $23.5 \mathrm{~kg}$ and $120.6 \mathrm{~cm}$, respectively.

Table 1: Characteristic distribution of Children according to School readiness

\begin{tabular}{|c|c|c|c|}
\hline \multirow[t]{2}{*}{ Characteristics } & \multicolumn{2}{|c|}{ School readiness } & \multirow[t]{2}{*}{ p-value } \\
\hline & $\begin{array}{l}\text { Ready for } \\
\text { school } \\
(n=109)\end{array}$ & $\begin{array}{l}\text { Not ready } \\
\text { for school } \\
(n=41)\end{array}$ & \\
\hline \multicolumn{4}{|l|}{ Genders (\%) } \\
\hline Male & $52(47)$ & $24(58)$ & 0.001 \\
\hline Female & $57(53)$ & $17(42)$ & \\
\hline Age, mean (SD) & $6.38(0.3)$ & $6.34(0.2)$ & 0.338 \\
\hline School readiness score & $100.7(3.4)$ & $87.6(3.4)$ & 0.000 \\
\hline Body weight $(\mathrm{kg})$, mean $(\mathrm{SD})$ & $23.5(6.0)$ & $20.4(5.1)$ & 0.007 \\
\hline Body height $(\mathrm{cm})$, mean $(\mathrm{SD})$ & $120.6(6.0)$ & $113.9(8.8)$ & 0.000 \\
\hline \multicolumn{4}{|l|}{ Maternal education (\%) } \\
\hline High school graduate & $96(88)$ & $25(61)$ & 0.001 \\
\hline Non high school graduate & $13(12)$ & $16(39)$ & \\
\hline \multicolumn{4}{|l|}{ Maternal employment status (\%) } \\
\hline Employed & $56(51)$ & $14(34)$ & 0.061 \\
\hline Non-employed & $54(49)$ & $26(66)$ & \\
\hline \multicolumn{4}{|c|}{ Early education/preschool enrollment (\%) } \\
\hline Yes & $85(80)$ & $16(40)$ & 0.000 \\
\hline No & $24(20)$ & $25(60)$ & \\
\hline \multicolumn{4}{|l|}{ Height for age (\%) } \\
\hline Normal & $106(97)$ & $22(54)$ & 0.000 \\
\hline Stunted & $3(3)$ & $19(46)$ & \\
\hline \multicolumn{4}{|l|}{ Socioeconomic status } \\
\hline Middle-upper & $94(86)$ & $22(54)$ & 0.000 \\
\hline Low & $15(14)$ & $19(46)$ & \\
\hline
\end{tabular}

Mothers who were high school graduate are more likely to have children who are more prepared to school compared to mothers who were not high school graduate. Furthermore, children who were enrolled in preschool or early education tend to be more ready to go to school. In regards of nutrition status, children who were stunted tend to be not ready for school. Based on socioeconomic status, there was a significant difference toward school readiness. Children who came from families with middle-upper socioeconomic status tend to be more ready for school.

Table 2 shows the results of univariate and multivariate analysis of factors that could influence the school readiness. We used logistic regression with $95 \%$ level of confidence. It was found that body weight; maternal education, preschool/early education enrollment, height for age and socioeconomic status affect the children's school readiness. The OR value of body weight was 1.12 , which means for every $1 \mathrm{~kg}$ increase of body weight, the school readiness increases by $12 \%$. Meanwhile, children with mothers who were high school graduate were 4.1 times more likely to be ready for schools. Children who were enrolled in preschool or early education were 5.1 more ready for schools than those who were not. The OR value of height for age was 21.6 (6.68:70.32), which means that children who were not stunted are 21 time more ready for schools than stunted children. Children who came from families with middle-upper socioeconomic status had 4.8 times more likely to be ready for schools.

Table 2: Univariate and multivariate analysis of factors that could influence school readiness

\begin{tabular}{|c|c|c|c|c|}
\hline Predictors & $\begin{array}{l}\text { Univariate OR } \\
(95 \% \mathrm{Cl})\end{array}$ & $p$-value & $\begin{array}{l}\text { Multivariate OR } \\
(95 \% \mathrm{Cl})\end{array}$ & $p$-value \\
\hline Genders & $0.7(0.32: 1.42)$ & 0.318 & $0.7(0.28: 2.07)$ & 0.576 \\
\hline Body weight & $1.12(1.02: 1.12)$ & 0.009 & $1.0(0.90: 1.09)$ & 0.921 \\
\hline Maternal education & $4.1(1.75: 9.63)$ & 0.001 & $2.6(0.82: 8.54)$ & 0.102 \\
\hline Maternal employment status & $1.92(0.91: 4.07)$ & 0.098 & $1.2(0.43: 3.30)$ & 0.717 \\
\hline $\begin{array}{l}\text { Preschool/early education } \\
\text { enrollment }\end{array}$ & $5.1(2.35: 11.11)$ & 0.000 & $6.5(2.28: 18.55)$ & 0.000 \\
\hline Height for age & $21.6(6.68: 70.32)$ & 0.000 & $34.4(7.19: 166.6)$ & 0.000 \\
\hline Socioeconomic status & $4.8(2.12: 10.89)$ & 0.000 & $4.8(1.59: 14.92)$ & 0.006 \\
\hline
\end{tabular}

After conducting multiple logistic regressions, it was found that the maternal weight, maternal education, maternal employment status, and socioeconomic status not affected the children's readiness to attend school. We found that preschool/early education enrollment and stunted were significantly associated with school readiness.

\section{Discussion}

School readiness is a condition when the child is ready physically, mentally, and the right skills to enter formal school. School readiness not only includes children's academic skills, but also physical health, language skills, social and emotional development, motivation to learn, creativity, and general knowledge. Emig described school readiness as a multidimensional concept, and this is reflected in three components identified by the US National Education Goals Panels. This comprised of children's readiness for school, school's readiness for children and family or community supports and services that contribute to children's readiness. These components could be divided further into internal factors and external factors. These 
are the factors that will affect children's language, motoric, social, and emotional development, which are necessary for the maturity of children entering the school world [6], [7].

There are various tests to assess school readiness. School readiness test aims to assess language, motoric and social development, as well as observing the ability of children to move from their parents or caregivers, interact with other children, attention, effort, and cooperation in conducting tests [7]. This study used NST to determine the school readiness of children to enter ES. This test was first arranged by Monks et al. and consists of ten subtest, with the test description contained pictures or complete the picture at once with the answers, which each aspects reveal different abilities, such as observation and ability to distinguish, fine motor, notions of large, number and comparison; sharpen observation; critical thinking ability; concentration; definition of object and situational assessment; imitating story and describing people [8].

The study by Rahmawati et al., revealed that there are two main factors influencing children's school readiness, namely cognitive factors which involve reading, writing, and calculating skills, and noncognitive factors which include socioemotional skills and its consistent correlation with socioemotional and academic outcomes. Cognitive factors are considered more important than noncognitive factors due to demands to master cognitive abilities to be accepted in favorite primary schools [9].

Kustimah et al. stated one of several factors in supporting the readiness of children to enter school is a good physical health. Good health with a balanced nutritional intake is important to affect school readiness. Healthy children will easier to digest the knowledge being taught also better socialize, appear nimble and vibrant, both in accepting information and in fostering social relations with teacher and their friends [10]. Nevertheless, stunting in early childhood is common in developing countries and has been shown to be associated with poorer cognition and school achievement in later childhood. Until now, stunting is one of the nutritional problems that need attention. About 8.8 million Indonesian children suffer from stunting. In Indonesia, the national prevalence for stunting based on the results of the 2013 Indonesian National Health Survey (Riskesdas) for children aged 6-12 years was $37.2 \%$ [11]. This number is high for the level of public health. This number increased from 2010, which was $35.6 \%$. In North Sulawesi province, the prevalence of stunting reached 35\% in 2013 [14]. According to a study by Bora et al. [12], it was found that stunting students had less learning achievement, while non-stunting students had better learning achievements.

In this study, 22 stunted children were obtained from anthropometric examination. From NST test of these stunted children, 19 children were not ready for school and 3 children were ready for school. Statistical analysis found a significant relationship between stunted and school readiness $(p<0.001)$. The odds ratio value of stunted in this study was 21.6 (6.68:70.32), which means that children who were not stunted are 21 time more ready for schools than stunted children. This finding is supported by a study conducted by Gashu et al. [13], who reported that children with stunting showed poor cognitive abilities. In the study, stunting children had low cognitive values on all psychological tests performed. This might be the cause for stunted children to be more unprepared in adapting to the school world.

The study by Casale and Desmond [14] also reported that children with stunting will have lower cognitive function compared to normal children. Stunted children who were quickly treated at $<2$ years of age could provide a better prognosis. In the study, children who received treatment after the age of 2 years showed poor cognitive function results compared to children who received treatment under the age of 2 years, and the results were almost as bad as children who were still stunted at that age. The same thing was reported by Picauly and Toy [15] who stated that stunting is one of the factors that influence learning achievement. Stunting is a manifestation of a disruption of longterm growth in the body, if this happens, and then one of the organs of the body that is at risk is the brain. Another finding was also reported by Semba et al. [16], who stated that stunted students show poor academic achievements, with two core problems, such as high number of absences and the low quality of absorption and mastery of learning material.

Based on the interviews conducted with parents of patients, there were 70 children with employed mothers. After the NST was performed on them, 14 children were not ready for school. Out of 80 children with unemployed mothers, 54 of them for school and 26 children were not ready for school. Statistical analysis showed no association between maternal employment status and school readiness $(p=0.25)$. This result is similar with a study conducted by Mariana et al. [17], which found no significant association between the employment status of mothers with cognitive development in preschool children $(p=0.05)$. A study by DeJong and Cho [18] showed that children from mothers who did not work showed less achievement compared to children from working mothers. However, there are several studies whose results are inversely proportional to the findings of this study, namely that non-working mothers have the possibility of having children who are better prepared to enter primary school than working mothers. Some of these studies mentioned that non-working mothers certainly have more time for their children, so that the growth and development of children is better monitored by mothers every day [19].

Maternal education status will correlate positively with how they care for children, as child care is closely related to child development. Child Trends 
Databank (2012) which is an independent institution in America shows that in general children with higher educated parents have better school readiness, especially cognitive abilities and reading. It can be concluded that the level of parental education can affect children's school readiness [20], [21] In this study, from the NST test results conducted on 29 children with mothers who did not graduate from high school, there were 16 children who were not ready for school. While from 121 mothers who graduated from high school, there were 96 children who were ready for school. Statistical analysis obtained association between maternal education statuses with school readiness $(p<0.0001)$. Children with mothers who were high school graduate were 4.1 times more likely to be ready for schools. A study by Schady [22] that there was an association between the educational status of parents and children's cognitive development. Even though, it is acknowledged that mothers are not solely responsible for ensuring their children's learning and development, researchers has documented the task specialization by gender in which women is still assume the domestic task with regular housework such as taking care of the children and engage in children education [23].

Almost all of the studies conducted to assess school readiness obtained socioeconomic status as one of the strong risk factors that affect the readiness of a child's school. It was found that the low level of school readiness was affected due to the lower socioeconomic status. Even though children who received earlier intervention were those from good socioeconomic status, this explained that there was an impact of socioeconomic status related to the quality of earlier intervention in a child [2], [22]. In this study of 34 children with lower socio-economic status, 19 children were not ready for school. Whereas from 116 children from middle-upper socioeconomic status, there were 94 children who were ready for school. From the analysis carried out, there is an influence of socioeconomic status on school readiness $(p<0.0001)$. Children who came from families with middle-upper socioeconomic status had 4.8 times more likely to be ready for schools. This finding is supported by another study by Ivanashvili et al. [24], that socioeconomic status has a large impact on school readiness, in which found that almost all children with families with lower socioeconomic status had low linguistic abilities ( $p<0.05)$. In addition, there was also a study by Raizada and Kishiyama [25] who found that children with lower socioeconomic status had poor cognitive development and school readiness.

Growing up in conditions of low socioeconomic status could affect children's outcome in multitudes of ways. Low socioeconomic status families often face significant economic and housing obstacles, among other barriers, that can diminish parent-infant relationship quality and socialization opportunities for children. Disruption in early social and emotional experiences might responsible for subsequent social incompetent and challenges in effective function of children. Perry et al. reported that challenges in social competence at kindergarten associated with poverty-related risks negatively impacted the children academic abilities related to math and literacy skills through challenges in executive function as first graders of ES [26]. Early Childhood Education or preschool is a level of education before primary education aimed at children from birth to the age of 6 years which is carried out through the provision of educational stimuli to help growth and physical and spiritual development so that children have readiness to enter further education held through formal, non-formal, and informal channels [27]. Early childhood interventions do boost children's confidence and social skills, which provides a better foundation for success at school (and subsequently in the workplace). Reviews of the research often infer that it is the social skills and improved motivation that lead to lower levels of special education and school failure and higher educational achievement in children exposed to early childhood development programs. However, there is clear evidence that cognitive, language and academic skills can also be enhanced by early education and care experience and these are likely to play a role in the later educational, social and economic success that is often found for well-implemented by early education and care experience interventions. Studies into adulthood indicate that this educational success is followed by increased success in employment, social integration and sometimes reduced criminality. There is also an indication of improved outcomes for mothers. The greatest improvements appear to occur for those problems that are endemic for the particular disadvantaged group, where there is greatest opportunity for improvement for example behaviour problems, criminality, and lack of educational achievement [28].

This study found that out of 49 children who did not attend preschool, 25 children were not ready, and 24 children were ready for school. While from 101 children who attended preschool, 85 of them were ready for school. Statistical analysis found a significant association between children's participation in preschool and school readiness $(p<0.0001)$. Children who were enrolled in preschool or early education were 5.1 more ready for schools than those who were not. Previous studies by Fasli [29] stated that children who attend preschool have better learning abilities than children who do not attend preschool. Magnuson et al. also found that children in center-based preschool programs in the year prior to school entry have better reading and math skill, and this advantage persists to the spring of first grade. These children were also less likely to repeat kindergarten [30].

Of the 5 factors that were analyzed, there were 2 factors that associated with school readiness, namely stunting and participation in preschool education. Stunting is one indicator of children's welfare, as it 
is the most prevalent form of child malnutrition, with prevalence of 161 million children worldwide in 2013. Linear growth failure serves as a marker of several pathological abnormalities associated with neurological and cognitive developmental disorders. It is important to increase awareness of the high prevalence of stunting children and its future consequences, where stunting has been identified as one of the main global health priorities [31].

Stunted children will experience a disruption in behavioral development, tend to have problem with taking school lessons, get lower grades, and have lower cognitive abilities than normal children. Stunted children tend to be more apathetic in social development, showing less curiosity when compared to normal children. Malnutrition will affect the area of the brain involved in cognitive, memory and motor skills. The brain has the main energy needs in early childhood and most brain development takes place in the first 2 years of life [32]. Pediatricians can play an important role for advocating the proper identification of childhood malnutrition and effective implementation and delivery of nutrition interventions. Ample nutrition specific interventions, including management of stunting and protein-energy malnutrition, promotion of breastfeeding and complementary feeding practices, micronutrient supplementation and food fortification, should be familiar to clinicians [33]. Government and policymakers have also responsibilities to address stunting among children by expand a national nutrition programs [34].

In regards of preschool education, government in Indonesia has been implementing policies and programs to prioritize early childhood education and development (ECD), and this has resulted an improvement in early childhood education and development (ECED) enrollment from $24.1 \%$ to $54.4 \%$ between 2000 and 2013 [35]. However, access to early education services was also facing disparities, where children from the lower socioeconomic families having significantly lower enrollment rates from the wealthier families. In term of this, it is important for the government and policymakers to increase ECD enrollment, while also establishing and maintaining the qualities of ECD facilities, such as accreditation and training opportunities for ECD educators [34], [35].

\section{Conclusion}

There were associations between height, maternal education status, socioeconomic status, and participation in preschool with school readiness. Height of the children was strongly associated with school readiness. There was no association observed between the employment status of mothers and school readiness. Appropriate strategies are needed to reduce factors that can negatively impact a child's readiness to school. There needs to be special attention to the readiness of children, especially in parents, educators and pediatricians. Various scattered early childhood education centers can be very helpful to prepare children to achieve optimal child quality in accordance with the potential of each child. Studies at various centers are needed to recognize factors that can affect a school child's readiness and can determine the right follow-up or strategy to improve the readiness of the child.

\section{References}

1. Indriyani SA, Soetjiningsih IG. Tumbuh Kembang Anak. $2^{\text {nd }}$ ed. School Readiness. Jakarta: EGC; 2012. p. 283-8.

2. Feigelman S. Nelson textbook of Pediatrics. $19^{\text {th }}$ ed. Middle Childhood. Tokyo: Igaku-Shoin/Saunders; 2011. p. 36.

3. Britto PR. School Readiness: A Conceptual Framework. New York: United Nations Children's Fund (UNICEF); 2012.

4. Fauziyah N. School readiness of preschool children entering elmentary school based on nijmeegse schoolbekwaamheids test (Nst) (case study at early chidhood education Al Husna Pengging Boyolali in2017). Early Child Res J. 2019;2:29-35

5. Srinahyanti S. Readiness to Attend Kindergarten Group B is Reviewed from the Educational Institution and the Level of Education of Parents. Perpustakaan Universitas Pendidikan Indonesia; 2013. p. 1-12. https://doi.org/10.24114/sejpgsd. v7i4.8178

6. Emig C. School readiness: Helping communities get children ready for school and schools ready for children. Child Trends Research Brief. 2000;ED444712:1-10.

7. Lumaurridli, Retnawati H, Kistoro HC, Putranta H. School readiness assessment: Study of early childhood educator experience. Ilkogretim Online. 2021;20(1):468-78. https://doi. org/10.17051/ilkonline.2021.01.041

8. Monks FJ, Rost H, Coffie NH. Nijmeegse Schoolbekwaamheids Test; 1978.

9. Rahmawati A, Tairas MM, Nawangsari NA. Children's school readiness based on teachers' and parents' perceptions. Indian J Prod Thermal Eng. 2018;2(1):9-120

10. Kustimah, Kusumawati, Abidin FA. Overview of readiness of children to enter elementary school in review of N.S.T. Bandung test results. J Psikol. 2008;21:1.

11. Salimar. Characteristics of short problems (Stunting) in children throughout Indonesia. Info Pangan Gizi. 2013;19(2):15-6.

12. Bora NG, Picauly I, Aspatria U. Analysis of determinants of stunting and its impact on the learning achievement of elementary school children in Waingapu City District of East Sumba Regency. J Pangan Gizi Kesehatan Masyarakat. 2012;4(3):1100-10.

13. Gashu D, Stoecker BJ, Bougma K, Adish A, Haki GD, Marquis GS. Stunting, selenium deficiency and anemia are associated with poor cognitive performance in preschool children from rural Ethiopia. Nutr J. 2016;15:38. https://doi.org/10.1186/ s12937-016-0155-Z

PMid:27067274

14. Casale D, Desmond C. Recovery from stunting and cognitive outcomes in young children: Evidence from the South African 
Birth to twenty cohort study. J Dev Orig Health Dis. 2016;(2):16371. https://doi.org/10.1017/S2040174415007175 PMid:26399543

15. Picauly I, Toy M. Analysis of determinants and influence of stunting on school children's learning performance in Kupang and East Sumba, NTT. J Gizi Pangan. 2013;8(1):55-62.

16. Semba RD, de Pee S, Kai S, Sari M, Akhter N, Bloem MW. Effect of parental formal education on risk of child stunting in Indonesia and Bangladesh: A cross-sectional study. Lancet. 2008;371(9609):322-8. http://doi.org/10.1016/ S0140-6736(08)60169-5

PMid:18294999

17. Mariana C, Ismanto AY, Babakal A. Relationship of the mother's employment status with the cognitive development of preschoolage children in preschool GMIM Bukit Hermon and Kindergarten Dhata Malalayang district of Manado city. eJ Keperawatan. 2015;3(2):1-8.

18. DeJong A, Cho SH. Working mother: Cognitive and behavioral effect on children. J Undergrad Res. 2010;8:75-82.

19. Istiqomah. School Readiness of Children is reviewed from the Perception of Communication Patterns with Parents. Prosiding Seminar Nasional Parenting; 2013. p. 97-105.

20. Maxwell KL, Clifford RM. School Readiness Assessment. Available from: http://journal.naeyc.org/btj/200401/maxwell.pdf [Last accessed on 2017 Aug 06].

21. Schady N. Parents' education, mothers' vocabulary, and cognitive development in early childhood: Longitudinal evidence from Ecuador. Am J Public Health. 2011;101(12):2299-307. http://doi.org/10.2105/AJPH.2011.300253

PMid:22021308

22. Mohammadzadeh A, Jafarzade M, Farhat AS, Amiri R, Esmaeh $\mathrm{H}$. Ophthalmic, hearing, speaking and school readiness outcomes in low birth weight and normal birth weight primary school children in Mashhad-Iran. Acta Med Iran. 2011;49(1):2832. https://doi.org/10.1155/2010/705382a

PMid:21425068

23. Galindo C, Susan S, Montoya-Ávila A. Latina mothers' engagement in children's math learning in the early school years: Conceptions of math and socialization practices. Early Child Res Q. 2019;47(1):271-83. https://doi.org/10.1016/j. ecresq.2018.11.007

24. Ivanashvili T, Tabatadze T, Kherkheulidze M, Karseladze R, Kandelaki E. Evaluation of school readiness outcomes in preterm and SGA infant. Int J Sci. 2016;27(2):7-20.

25. Raizada RD, Kishiyama MM. Effects of socioeconomic status on brain development, and how cognitive neuroscience may contribute to levelling the playing field. Hum Neurosci. 2010;4:38. https://doi.org/10.3389/neuro.09.003.2010

26. Perry R, Braren SH, Blair C, Family Life Project Key Investigators. Socioeconomic risk and school readiness: Longitudinal mediation through children's social competence and executive function. Front Psychol 2018;9:1-15. https://doi. org/10.3389/fpsyg.2018.01544

27. Yamin M, Sanan SS. Early Childhood Education Guide. Jakarta: Gaung Persada Press; 2010. p. 1-38.

28. Melhuish E, Stevens KE, Petrogiannis K, Ariescu A, Penderi E, Rentzou K, et al. A review of research on the effects of early childhood Education and Care (ECEC) upon child development. CARE project. CARE Project. 2015;613318:1-84.

29. Fasli J. Early childhood education, fundamental education. J PADU. 2002;1:4-8.

30. Magnuson K, Meyers MK, Ruhm CJ, Waldfog J. Inequality in preschool education and school readiness. Am Educ Res J 2004;41:115. https://doi.org/10.3102/00028312041001115

31. Onis M, Branca F. Childhood stunting: a global perspective. Matern Child Nutr. 2016;12:12-26. https://doi.org/10.1111/ mcn.12231

PMid:27187907

32. Prendergast AJ, Humphrey $\mathrm{JH}$. The stunting syndrome in developing countries. Paediatr Int Child Health. 2014;34(4):25065. https://doi.org/10.1179/2046905514Y.0000000158 PMid:25310000

33. Suchdev PS. What pediatricians can do to address malnutrition globally and at home. Pediatrics. 2017;139(2):e20161666. https://doi.org/10.1542/peds.2016-1666

PMid:28062600

34. Denboba A, Hasan A, Wodon Q. Early Childhood Educational and Development in Indonesia. Washington, DC: Internation Bank for Reconstruction and Development/The World Bank; 2015. p. 20-35.

35. Nakajima $N$, Hasan A, Jung $H$, Brinkman S, Pradhan $M$, Kinnell A. Investing in School Readiness: An Analysis of the Cost-effectiveness of Early Childhood Education Pathways in Rural Indonesia. Policy Research Working Paper Series, No. 7832. Washington, DC: The World Bank. 